$14^{\text {th }}$ Conf. Agric. Develop. Res., Fac. of Agric., Ain Shams Univ., March, 2019, Cairo, Egypt

Special Issue, 27(1), 877 - 886, 2019

Website: http://strategy-plan.asu.edu.eg/AUJASCl/

\title{
IMPACT OF INFECTION WITH FASCIOLA Spp. ON PRODUCTIVE PER- FORMANCE AND CARCASS CHARACTERISTICS IN RABBITS
}

[80]

\author{
Mohammed M.S. ${ }^{1}$, EI- Shinawy ${ }^{2}$, M.Z., EL-Hommosany K.M. ${ }^{1}$, \\ Mahrous M.Y. ${ }^{3}$ and Galal A. ${ }^{3}$
}

1. Environmental Researches and Malacology Dept., Theodor Bilahars Institute, Giza, Egypt

2. Horticulture Dept., Fac. of Agric., Ain Shams Univ., P.O. Box 68, Hadyek Shoubra 11241, Cairo, Egypt

3. Poultry Production Dept., Fac. of Agric., Ain Shams Univ., P.O. Box 68, Hadyek Shoubra 11241, Cairo, Egypt

*Corresponding author: malacology_tbri@yahoo.com

Accepted 30 December, 2018

\begin{abstract}
Liver fluke are common parasites of herbivores in most of Middle East countries as Egypt. The chronic and acute infections with 10 \& 20 metacercaria of this parasite cause biliary liver cirrhosis in rabbits that lead to huge economic losses. This cross-sectional study was carried out to determine the prevalence of fascioliosis in slaughtered rabbits in Giza governorate. In Egypt Fasciola gigantica was responsible for $\mathrm{V}$-Line and Black Baladi rabbits total liver condemnations in infected groups. The infection impacts on female rabbits were more than males $(p<.0001)$ in most groups for both strains.

Liver condemnations due to fascioliasis were more affected in body weight and feed consumption, feed conversion, heart, kidney and carcass characterestic, so it's low economic efficiency. Blood parametars showed high significant $(p<.0001)$ between treated groups of strains.
\end{abstract}

Keywords: Fasciola infection, productive performance, carcass, rabbits.

\section{INTRODUCTION}

Fascioliasis is a hepatic parasitic infection in many mammalian species. The pathogenic effect on the definitive host begins with the ingestion of metacercariae, which become excysted and re- leased the juvenile fluke in the intestinal lumen. The juvenile flukes then migrate through the intestinal wall into the peritoneal cavity and penetrate into the liver through the liver capsule. In some parasitic diseases, liver is an important organ that is infected with parasites (Malone et al 1998 and Ansari-Lari \& Moazzeni, 2006).

Rabbits fed with parasites can cause reduction on number of progeny production and many disorders such as diarrhea, loss of weight gain, abdominal pain and anemia. Fascioliasis considered the top of all the domestic rabbit's parasitic zoonotic worldwide infection that is endemic in a tropical area and Egypt (Haridy et al $\mathbf{2 0 0 2}$ and Amer et al 2016). Fascioliasis reduces animal productivity, weight gain and production of meat and milk. In addition, it causes metabolic disorders, and secondary infections due to decrease immunity by chronic fascioliasis and liver condemnation during postmortem of carcass while the acute fascioliasis may lead to mortalities (Mason, 2009 and Eman et al 2016).

\section{MATERIALS AND METHODS}

This study was carried out at Poultry Production Department, Faculty of Agriculture, Ain Shams University. A total number of 36 rabbits (18 white V- Line rabbit and 18 Black local breed) aging (2) months, weighted about $2 \mathrm{~kg}$ when used in present work (Obtained from Faculty of Agriculture Farm, 
Alex University). Each strain was divided into 3 groups (Control group, treated group with 10MC and treated group with $20 \mathrm{MC}$ ) each group contains 6 rabbits. They fed on standard pellet diet, the pelleted experimental diets were formulated to be approximately which incorporated at $0,200 \mathrm{mg} / \mathrm{kg}$. The animals kept in suitable temperature and clean cages, housing size $45 \mathrm{~cm}{ }^{*} 55 \mathrm{~cm}$.

The rabbits were housed in galvanized metal wire cages and kept under the same managerial and hygienic conditions. Diets and fresh water were available all times.

Live body weight of rabbits and feed consumption were weekly recorded. Feed conversion ratio was calculated as (g feed/g gain) (Hala Gamal ElDein and Azza Mostafa, 2012).

At the end of experimental period, three representative rabbits from each group were randomly chosen and fasted for 12 hour before slaughtering according to (Blasco et al 1993), and also carcass traits and plasma parameters were determined. After complete bleeding of rabbits, pelt, viscera and tail were removed. Carcass and the following tissues (liver, heart, and kidney) were weighed.

Blood samples were collected at slaughtering into heparinized tubes. Blood samples were centrifuged at 4000 r.p.m. for 20 minutes for preparation of blood plasma. The collected plasma was stored at $-20^{\circ} \mathrm{C}$ until assay.

Blood plasma contents of glucose, total protein, albumin, activities of aspartate amino transferase (AST) alanine aminotransferase (ALT), Creatinine and Urea were measured using commercial kits (Biodiagnostics Company). Blood plasma was analysed for total protein according to (Peters, 1968), albumin (Doumas et al 1917), glucose (Trinder, 1969), activities of AST and ALT (Har- old, 1975), urea (Pisani et al 1995) and creatinine (Greiling and Gressner, 1995).

\section{Statistical analysis}

Data were subjected to a two-way analysis of variance using the General Linear Model (GLM) procedure of (SAS, 2004) using the following model:

$$
Y i j=\mu+S i+T i+\left(S i^{*} T i\right)+e i j
$$

Where;

Yij = Trait measured, $\mu=$ Overall means, $\mathrm{Si}=$ Strain effect, $\mathrm{Ti}=$ Treatment effect, $\left(\mathrm{Si}{ }^{\star} \mathrm{Ti}\right)=$ Interaction effect and eij $=$ Experimental error

When significant differences among means were found, means were separated using Duncan's multiple range tests (Duncan, 1955).

\section{RESULTS AND DISCUSSION}

\section{Productive performance}

\subsection{Body weight and body weight gain}

The body weight in (Table 1) showed a significant increase affected by strain factor, control group of V-Line and Black Baladi recorded a higher significant increase compared to treated groups at (4,8 and $12 \mathrm{wk})$ after infection. At the end period of infection, there were a highly significant decrease in body weight $(p<.0001)$ for group when infected with (20 MC). this group shown an acute symptoms and the lowest body weight compared to all groups as follow $(3.27 \mathrm{Kg}$ Cont. , $2.07 \mathrm{Kg}$ for $10 \mathrm{MC} \& 1.192 \mathrm{Kg}$ for $20 \mathrm{MC})$ for "BB strain". And (3.7 Kg Cont. , $2.02 \mathrm{Kg}$ for $10 \mathrm{MC} \& 1.86 \mathrm{Kg}$ for 20 $\mathrm{MC})$ for "VL strain" at 12 week of age.

Table 1. Means and (SE) of live body weight for two rabbit strains affected by fascioliases.

\begin{tabular}{|c|c|c|c|c|c|c|c|c|}
\hline \multirow{2}{*}{ Trait } & \multirow{2}{*}{ Strain } & \multicolumn{3}{|c|}{ Treatment } & \multirow{2}{*}{ Overall (strain) } & \multicolumn{3}{|c|}{ Prob. } \\
\hline & & Control & $10 \mathrm{MC}$ & $20 \mathrm{MC}$ & & tr & st & $\operatorname{tr}^{*} s t$ \\
\hline $\begin{array}{c}\text { Initial } \\
\text { Body wt. }\end{array}$ & $\begin{array}{c}\text { Baladi } \\
\text { VL } \\
\text { Overall (trait) }\end{array}$ & $\begin{array}{c}2.02 \pm 0.03 \\
1.95 \pm 0.04 \\
1.98\end{array}$ & $\begin{array}{c}1.99 \pm 0.02 \\
2.01 \pm 0.03 \\
2.005 \\
\end{array}$ & $\begin{array}{c}2.00 \pm 0.04 \\
1.99 \pm 0.04 \\
1.99\end{array}$ & $\begin{array}{c}2.005 \\
1.98 \\
1 .\end{array}$ & NS & NS & NS \\
\hline $\begin{array}{c}4 \text { weeks } \\
(\mathrm{kg})\end{array}$ & $\begin{array}{c}\text { Baladi } \\
\text { VL } \\
\text { Overall (trait) }\end{array}$ & $\begin{array}{c}2.66 \pm 0.007 \\
2.85 \pm 0.02 \\
2.75^{a}\end{array}$ & $\begin{array}{c}2.58 \pm 0.007 \\
2.61 \pm 0.04 \\
2.60^{\mathrm{b}}\end{array}$ & $\begin{array}{c}2.45 \pm 0.009 \\
2.46 \pm 0.02 \\
2.46^{c}\end{array}$ & $\begin{array}{l}2.57^{b} \\
2.64^{a} \\
{ }^{a}\end{array}$ & $<.0001$ & $<.0001$ & 0.0004 \\
\hline $\begin{array}{c}8 \text { weeks } \\
(\mathrm{kg})\end{array}$ & $\begin{array}{c}\text { Baladi } \\
\text { VL } \\
\text { Overall (trait) } \\
\end{array}$ & $\begin{array}{c}3.17 \pm 0.01 \\
3.57 \pm 0.01 \\
3.37^{\mathrm{a}} \\
\end{array}$ & $\begin{array}{c}2.29 \pm 0.006 \\
2.27 \pm 0.03 \\
2.28^{\mathrm{b}} \\
\end{array}$ & $\begin{array}{c}2.19 \pm 0.01 \\
2.12 \pm 0.03 \\
2.15^{c} \\
\end{array}$ & $\begin{array}{l}2.55^{b} \\
2.66^{a} \\
\end{array}$ & $<.0001$ & $<.0001$ & $<.0001$ \\
\hline $\begin{array}{c}12 \text { weeks } \\
(\mathrm{kg})\end{array}$ & $\begin{array}{c}\text { Baladi } \\
\text { VL } \\
\text { Overall (trait) }\end{array}$ & $\begin{array}{c}3.27 \pm 0.009 \\
3.7 \pm 0.002 \\
3.49^{\mathrm{a}}\end{array}$ & $\begin{array}{c}2.07 \pm 0.01 \\
2.06 \pm 0.02 \\
2.06^{\mathrm{b}}\end{array}$ & $\begin{array}{c}1.92 \pm 0.01 \\
1.86 \pm 0.02 \\
1.89^{c}\end{array}$ & $\begin{array}{l}2.42^{b} \\
2.54^{a}\end{array}$ & $<.0001$ & $<.0001$ & $<.0001$ \\
\hline
\end{tabular}


Results of body weight gain that showed in (Table 2) referred to a significant decrease at the age period between (4-12 wk) to the group infected with (20 MC) for both Baladi (-0.044 kg at 12 week) and V-Line $(-0.08 \mathrm{~kg}$ at 12 week) strains, compared to control and the group infected with (10 $\mathrm{MC})$.

In this study, we have two strains of rabbit to proved which strain has a highly immune against infections with a recognized negative impact on rabbits herds production in Egypt that have a temperate climate zone. Tasawar et al (2007) reported that the body weight that decreases because the animal increases the parasitic infection, this could be due to acquired immunity in the host. It was concluded that the prevalence of Fasciola hepatica in rabbit was significantly affected by the breed, age and body weight of the animal.

The infection start to appear at rabbits at the fourth week from date of infection with Fasciola, simultaneity with decrease in body weight, dispite of the normal consumed of feed (Table 1). In this study, the results proved that the live body weight and the quality fur of infected rabbit groups is poor and loss of hair coat compared control. Rabbit showing emaciation, loss of hair coat (Mahmoud et al 2010).

Table 2. Means and (SE) of live body weight gain for two rabbit strains affected by fascioliases.

\begin{tabular}{|c|c|c|c|c|c|c|c|c|}
\hline \multirow{2}{*}{ Trait } & \multirow{2}{*}{ Strain } & \multicolumn{3}{|c|}{ Treatment } & \multirow{2}{*}{$\begin{array}{l}\text { Overall } \\
\text { (strain) }\end{array}$} & \multicolumn{3}{|c|}{ Prob. } \\
\hline & & Control & $10 \mathrm{MC}$ & $20 \mathrm{MC}$ & & $\operatorname{tr}$ & st & $\operatorname{tr}^{*} s t$ \\
\hline \multirow{3}{*}{$0-4$ weeks } & Baladi & $0.165 \pm 0.02$ & $0.152 \pm 0.02$ & $-0.018 \pm 0.01$ & $0.099^{b}$ & & & \\
\hline & VL & $0.226 \pm 0.01$ & $0.179 \pm 0.03$ & $0.116 \pm 0.01$ & $0.174^{a}$ & $<.0001$ & $<.0001$ & $<.05$ \\
\hline & Overall (trait) & $0.19^{a}$ & $0.16^{b}$ & $0.049^{b}$ & & & & \\
\hline \multirow{3}{*}{ 4-8 weeks } & Baladi & $0.125 \pm 0.01$ & $-0.072 \pm 0.01$ & $-0.044 \pm 0.01$ & $0.002^{a}$ & & & \\
\hline & VL & $0.132 \pm 0.01$ & $-0.022 \pm 0.02$ & $-0.084 \pm 0.02$ & $0.008 \mathrm{a}$ & $<.0001$ & NS & $<.05$ \\
\hline & Overall (trait) & $0.12^{a}$ & $-0.047^{b}$ & $-0.064^{b}$ & & & & \\
\hline \multirow{3}{*}{ 8-12 weeks } & Baladi & $-0.002 \pm 0.007$ & $-0.065 \pm 0.01$ & $-0.061 \pm 0.004$ & -0.042 & & & \\
\hline & VL & $0.0125 \pm 0.01$ & $-0.056 \pm 0.007$ & $-0.065 \pm 0.01$ & -0.036 & $<.0001$ & NS & NS \\
\hline & Overall (trait) & $0.005^{a}$ & $-0.06^{b}$ & $-0.063^{b}$ & & & & \\
\hline \multirow{3}{*}{$\begin{array}{l}\text { Cum. } \\
\text { BWG }\end{array}$} & Baladi & $1.258 \pm 0.03$ & $0.0775 \pm 0.03$ & $-0.072 \pm 0.05$ & $0.421^{b}$ & & & \\
\hline & VL & $1.75 \pm 0.04$ & $0.0501 \pm 0.05$ & $-0.121 \pm 0.04$ & $0.559^{a}$ & $<.0001$ & $<.0001$ & $<.0001$ \\
\hline & Overall (trait) & $1.504^{\mathrm{a}}$ & $0.063^{b}$ & $-0.097^{c}$ & & & & \\
\hline
\end{tabular}

Hawkins and Morris (1978) demonstrated that weekly growth rates of weight gain and live weight decreased with increasing fluke burdens in the infected animals.

Weight gain is an observable phenomenon and reduced weight gain can prompt nematode control in herd of breeding (Hoglund et al 2009).

The effects of $F$. hepatica infections on weight gain and wool growth were in agreement with results of (Dargie, 1987).

\subsection{Feed Consumption and Feed Conversion Ratio}

In the current study, (Table 3) showed that feed consumption recorded a significantly $(p<.0001)$ decreased levels in the end of experi- ment period at 12 wk for both infected group to Baladi and V-Line strain compared to control as follow (16.193 ${ }^{\text {Cont. }}, 11.685^{10 M C}, 10.203^{20 M C}$ for "BB \& VL").

The feed conversion ratio recorded a significant $(p<.0001)$ differences between Baladi and V-Line strains, traits effect showed in the end of experiment period at $12 \mathrm{wk}$ increase for 10 \& $20 \mathrm{MC}$ compared control $\left(6.15^{\text {Cont. }}, 13.25^{10 \mathrm{MC}}, 17.4^{20 \mathrm{MC}}\right)$ for FCR], respectively (Table 4).

Appetite was low and the prevalence of fascioliasis was significantly affected by the breed, feed consumption of the herd (Tasawar et al 2007). Furthermore, fascioliasis also led to a loss of appetite and poor utilization of food, which results in a loss of body weight (Ahmed et al 2007). 
Table 3. Means and (SE) of feed conversion ratio for two rabbit strains affected by fascioliases.

\begin{tabular}{|c|c|c|c|c|c|c|c|c|}
\hline \multirow{2}{*}{ Trait } & \multirow{2}{*}{ Strain } & \multicolumn{3}{|c|}{ Treatment } & \multirow{2}{*}{$\begin{array}{l}\text { Overall } \\
\text { (strain) }\end{array}$} & \multicolumn{3}{|c|}{ Prob. } \\
\hline & & Control & $10 \mathrm{MC}$ & $20 \mathrm{MC}$ & & tr & st & $\operatorname{tr}^{*} s t$ \\
\hline \multirow{3}{*}{$0-4$ weeks } & Baladi & $\begin{array}{l}6.739 \\
\pm 1.51\end{array}$ & $\begin{array}{l}10.099 \\
\pm 1.36\end{array}$ & $\begin{array}{l}17.99 \\
\pm 6.01\end{array}$ & $11.61 \mathrm{a}$ & & & \\
\hline & VL & $\begin{array}{l}5.335 \\
\pm 0.61\end{array}$ & $\begin{array}{l}7.565 \\
\pm 1.36\end{array}$ & $\begin{array}{c}7.57 \\
\pm 1.19\end{array}$ & $6.82 \mathrm{~b}$ & 0.042 & 0.001 & 0.04 \\
\hline & Overall (trait) & $6.037 \mathrm{c}$ & $8.83 \mathrm{~b}$ & $12.78 \mathrm{a}$ & & & & \\
\hline \multirow{3}{*}{ 4-8 weeks } & Baladi & $\begin{array}{l}7.377 \\
\pm 1.11\end{array}$ & $\begin{array}{c}10.936 \\
\pm 5.3\end{array}$ & $\begin{array}{c}21.140 \\
\pm 5.40\end{array}$ & $13.15 \mathrm{a}$ & & & \\
\hline & VL & $\begin{array}{l}5.150 \\
\pm 1.19\end{array}$ & $\begin{array}{l}16.240 \\
\pm 8.002\end{array}$ & $\begin{array}{c}8.04 \\
\pm 1.34\end{array}$ & $9.81 \mathrm{~b}$ & $<.0001$ & 0.0001 & NS \\
\hline & Overall (trait) & $6.264 \mathrm{c}$ & $13.588 b$ & $14.59 \mathrm{a}$ & & & & \\
\hline \multirow{3}{*}{ 8-12 weeks } & Baladi & $\begin{array}{c}7.55 \\
\pm 0.28\end{array}$ & $\begin{array}{l}16.60 \\
\pm 5.94\end{array}$ & $\begin{array}{c}19.369 \\
\pm 4.14\end{array}$ & 14.50 & & & \\
\hline & VL & $\begin{array}{l}6.535 \\
\pm 0.26\end{array}$ & $\begin{array}{l}15.89 \\
\pm 8.77\end{array}$ & $\begin{array}{l}20.33 \\
\pm 9.71\end{array}$ & 14.25 & $<.0005$ & NS & NS \\
\hline & Overall (trait) & $7.04 \mathrm{c}$ & $16.25 b$ & $19.84 \mathrm{a}$ & & & & \\
\hline \multirow{3}{*}{$\begin{array}{c}\text { Cumulative } \\
\text { FCR }\end{array}$} & Baladi & $\begin{array}{c}7.83 \\
\pm 0.64\end{array}$ & $\begin{array}{l}12.106 \\
\pm 2.001\end{array}$ & $\begin{array}{l}15.35 \\
\pm 4.43\end{array}$ & 11.76 & & & \\
\hline & VL & $\begin{array}{l}4.484 \\
\pm 4.07\end{array}$ & $\begin{array}{l}14.403 \\
\pm 7.05\end{array}$ & $\begin{array}{l}19.45 \\
\pm 8.25\end{array}$ & 12.77 & $<.0001$ & NS & NS \\
\hline & Overall (trait) & $6.15 c$ & $13.25 \mathrm{~b}$ & $17.4 \mathrm{a}$ & & & & \\
\hline
\end{tabular}

\section{Effect of treatments on body organs weight}

\subsubsection{Liver}

Hepatic damage was evaluated in this study, it assessed by visual inspection. Evaluation showed that bile duct had a worms, so liver a statistically significant increase in weight in both strains infected with $F$. gigantica compared to the control $(\mathrm{p}<.0001)$.

Liver section of rabbit infected with $F$. gigantica showed the worm resided in the bile ducts (Sherif et al 2005). Charlier et al (2008). A previous study found that worms of the major bile ducts only detected $29 \%$ of the infected livers.

\subsubsection{Kidney}

Kidney weight recorded highly significant difference between traits $(P<.0001)$, data showed dissimilarity for control group and 10, $20 \mathrm{MC}$. Renal changes in response to fascioliasis in rabbits varied among the studied animals. These results for kidney were in agreement with results of (Mesele et al 2012).

\subsubsection{Lungs}

Our results showed that lungs have venous congestion hemorrhagic spots and high significance overall for acute and chronic cases $(p<.0001)$. The changes in the lung from different experimental groups showing diffused interstitial inflammatory reaction and giant alveoli and showing chronic venous congestion in the lung tissue and some infected groups showing vasculitis and mild interstitial inflammatory reaction (Mesele et al 2012 and Mendes et al 2012).

\subsubsection{Heart}

Heart is an important organ and any change abnormal cause rapidly crisis in vitality and production performance, the data showed hemorrhage a highly significant traits $(p<.0001)$ for infected groups with 10 \& $20 \mathrm{MC}$ compared to control. Fascioliasis affects on the heart leading to heart condemnation in carcass of rabbits according to (Bala et al 2011). 

characteristics in rabbits

Table 4. Means and (SE) of carcass characteristics for two rabbit strains affected by fascioliases.

\begin{tabular}{|c|c|c|c|c|c|c|c|c|}
\hline \multirow{2}{*}{ Trait } & \multirow{2}{*}{ Strain } & \multicolumn{3}{|c|}{ Treatment } & \multirow{2}{*}{$\begin{array}{l}\text { Overall } \\
\text { (strain) }\end{array}$} & \multicolumn{3}{|c|}{ Prob. } \\
\hline & & Control & $10 \mathrm{MC}$ & $20 \mathrm{MC}$ & & tr & st & $\operatorname{tr}^{*} \mathbf{s t}$ \\
\hline \multirow{7}{*}{ Live body weight (g) } & \multirow{2}{*}{ Baladi } & 1708.67 & 942.33 & 786.67 & \multirow{2}{*}{$1128.39 b$} & \multirow{5}{*}{$<.0001$} & \multirow{5}{*}{$<.0001$} & \multirow{5}{*}{ NS } \\
\hline & & \pm 36.88 & \pm 40.01 & \pm 45.31 & & & & \\
\hline & \multirow{2}{*}{$\mathrm{VL}$} & 2097.67 & 1050.67 & 909.33 & \multirow{2}{*}{$1538.78 \mathrm{a}$} & & & \\
\hline & & \pm 40.65 & \pm 19.94 & \pm 59.65 & & & & \\
\hline & Overall (trait) & $1894.25 a$ & $991.00 \mathrm{~b}$ & $845.50 c$ & & & & \\
\hline & \multirow{2}{*}{ Baladi } & 51.01 & 43.80 & 37.80 & \multirow{2}{*}{$44.21 \mathrm{~b}$} & \multirow{4}{*}{$<.0001$} & \multirow{4}{*}{$<.0001$} & \multirow{5}{*}{ NS } \\
\hline & & \pm 0.85 & \pm 1.63 & \pm 2.07 & & & & \\
\hline Carcass \% & \multirow{2}{*}{ VL } & 57.20 & 53.06 & 39.78 & \multirow{2}{*}{$50.01 \mathrm{a}$} & & & \\
\hline & & \pm 1.03 & \pm 2.20 & \pm 1.49 & & & & \\
\hline & Overall (trait) & $54.10 \mathrm{a}$ & $48.43 \mathrm{~b}$ & $38.79 \mathrm{c}$ & & & & \\
\hline \multirow{5}{*}{$\begin{array}{l}\text { Head wt. } \\
\text { (g) }\end{array}$} & \multirow{2}{*}{ Baladi } & 107.4 & 104.69 & 102.58 & \multirow{2}{*}{$105.55 b$} & \multirow{4}{*}{0.05} & \multirow{5}{*}{0.032} & \\
\hline & & \pm 4.04 & \pm 2.91 & \pm 3.52 & & & & \\
\hline & $\mathrm{y}$ & 115.1 & 107.5 & 105.32 & \multirow{2}{*}{$110.2 a$} & & & NS \\
\hline & VL & \pm 6.00 & \pm 2.85 & \pm 2.90 & & & & \\
\hline & Overall (trait) & $112.3 a$ & $106.77 b$ & $104.74 b$ & & & & \\
\hline & Baladi & 23.21 & 39.66 & 60.66 & 4118 & & & \\
\hline & Dalaul & \pm 1.47 & \pm 2.23 & \pm 3.34 & 41.10 & & & \\
\hline Liver wi. & 8 & 22.21 & 39.81 & 51.36 & 378 & $<.0001$ & 0.05 & 0.05 \\
\hline & L & \pm 1.38 & \pm 1.94 & \pm 0.91 & 31.0 & & & \\
\hline & Overall (trait) & $22.71 \mathrm{c}$ & $39.74 \mathrm{~b}$ & $56.01 \mathrm{a}$ & & & & \\
\hline & Baladi & 5.38 & 6.25 & 7.05 & 6.22 & & & \\
\hline Kidney wt. & & \pm 0.10 & \pm 0.18 & \pm 0.19 & & & & \\
\hline (g) & VL & 5.40 & 5.98 & 6.53 & 5.97 & $<.0001$ & NS & NS \\
\hline & & \pm 0.07 & \pm 0.10 & \pm 0.22 & & & & \\
\hline & Overall (trait) & $5.39 \mathrm{c}$ & $6.11 \mathrm{~b}$ & $6.79 \mathrm{a}$ & & & & \\
\hline & Baladi & 5.70 & 8.20 & 8.11 & 7.33 & & & \\
\hline Lunas wt. & & \pm 0.12 & \pm 0.21 & \pm 0.32 & & & & \\
\hline (q) & $\mathrm{VL}$ & 5.56 & 8.25 & 8.61 & 747 & $<.0001$ & NS & NS \\
\hline & & \pm 0.08 & \pm 0.36 & \pm 0.33 & & & & \\
\hline & Overall (trait) & $5.63 \mathrm{~b}$ & $8.22 \mathrm{a}$ & $8.36 \mathrm{a}$ & & & & \\
\hline & Baladi & 2.18 & 2.76 & 2.84 & $259 \mathrm{a}$ & & & \\
\hline Heart wt & Sorich & \pm 0.04 & \pm 0.09 & \pm 0.10 & & & & \\
\hline (a) & $\mathrm{VL}$ & 2.19 & 2.55 & 2.61 & $243 \mathrm{~b}$ & $<.0001$ & 0.007 & NS \\
\hline & & \pm 0.06 & \pm 0.04 & \pm 0.03 & & & & \\
\hline & Overall (trait) & $2.18 \mathrm{~b}$ & $2.66 \mathrm{a}$ & $2.70 \mathrm{a}$ & & & & \\
\hline
\end{tabular}


Table 5. Means and (SE) of blood parameters for two rabbit strains affected by fascioliases.

\begin{tabular}{|c|c|c|c|c|c|c|c|c|}
\hline \multirow{2}{*}{ Trait } & \multirow{2}{*}{ Strain } & \multicolumn{3}{|c|}{ Treatment } & \multirow{2}{*}{$\begin{array}{l}\text { Overall } \\
\text { (strain) }\end{array}$} & \multicolumn{3}{|c|}{ Prob. } \\
\hline & & Control & $10 \mathrm{MC}$ & $20 \mathrm{MC}$ & & tr & st & tr*st $^{*}$ \\
\hline \multirow{3}{*}{$\begin{array}{l}\text { Total } \\
\text { Protein } \\
(\mathrm{mg} / \mathrm{dl})\end{array}$} & Baladi & $\begin{array}{c}5.22 \\
\pm 0.14\end{array}$ & $\begin{array}{c}6.89 \\
\pm 0.21\end{array}$ & $\begin{array}{c}8.72 \\
\pm 0.17\end{array}$ & 6.94 & & & \\
\hline & VL & $\begin{array}{c}5.53 \\
\pm 0.03\end{array}$ & $\begin{array}{r}6.97 \\
\pm 0.06\end{array}$ & $\begin{array}{c}8.53 \\
\pm 0.17\end{array}$ & 7.01 & $<.0001$ & NS & NS \\
\hline & Overall (trait) & $5.37 c$ & $6.93 \mathrm{~b}$ & $8.62 \mathrm{a}$ & & & & \\
\hline \multirow{3}{*}{$\begin{array}{l}\text { Plasma } \\
\text { Albumin } \\
\text { (mg/dl) }\end{array}$} & Baladi & $\begin{array}{c}2.33 \\
\pm 0.06\end{array}$ & $\begin{array}{c}3.46 \\
\pm 0.13\end{array}$ & $\begin{array}{c}3.60 \\
\pm 0.03\end{array}$ & 3.13 & & & \\
\hline & VL & $\begin{array}{c}2.16 \\
\pm 0.04\end{array}$ & $\begin{array}{c}3.34 \\
\pm 0.09\end{array}$ & $\begin{array}{c}3.53 \\
\pm 0.08\end{array}$ & 3.01 & $<.0001$ & NS & NS \\
\hline & Overall (trait) & $2.24 \mathrm{~b}$ & $3.40 \mathrm{a}$ & $3.56 \mathrm{a}$ & & & & \\
\hline \multirow{3}{*}{$\begin{array}{l}\text { AST } \\
\text { (U/L) }\end{array}$} & Baladi & $\begin{array}{l}32.46 \\
\pm 0.47\end{array}$ & $\begin{array}{l}55.56 \\
\pm 1.83\end{array}$ & $\begin{array}{l}73.92 \\
\pm 0.72\end{array}$ & 53.98 & & & \\
\hline & VL & $\begin{array}{l}34.61 \\
\pm 0.21\end{array}$ & $\begin{array}{l}50.16 \\
\pm 2.11\end{array}$ & $\begin{array}{l}72.50 \\
\pm 0.93\end{array}$ & 52.42 & $<.0001$ & NS & 0.02 \\
\hline & Overall (trait) & $33.53 \mathrm{c}$ & $52.86 \mathrm{~b}$ & $73.21 \mathrm{a}$ & & & & \\
\hline \multirow{3}{*}{$\begin{array}{l}\text { ALT } \\
(\mathbf{U} / \mathrm{L})\end{array}$} & Baladi & $\begin{array}{l}16.24 \\
\pm 0.32\end{array}$ & $\begin{array}{l}17.88 \\
\pm 0.31\end{array}$ & $\begin{array}{l}25.61 \\
\pm 0.71\end{array}$ & 19.91 & & & \\
\hline & VL & $\begin{array}{l}15.99 \\
\pm 0.30\end{array}$ & $\begin{array}{l}19.02 \\
\pm 0.44\end{array}$ & $\begin{array}{l}23.59 \\
\pm 0.63\end{array}$ & 19.53 & $<.0001$ & NS & 0.0105 \\
\hline & Overall (trait) & $16.11 \mathrm{c}$ & $18.45 b$ & $24.60 \mathrm{a}$ & & & & \\
\hline \multirow{3}{*}{$\begin{array}{l}\text { Plasma } \\
\text { Glucose } \\
\text { (mg/dl) }\end{array}$} & Baladi & $\begin{array}{c}109.36 \\
\pm 0.66\end{array}$ & $\begin{array}{l}95.19 \\
\pm 1.24\end{array}$ & $\begin{array}{l}83.65 \\
\pm 1.43\end{array}$ & 96.07 & & & \\
\hline & VL & $\begin{array}{l}105.89 \\
\pm 1.45\end{array}$ & $\begin{array}{l}95.99 \\
\pm 1.22\end{array}$ & $\begin{array}{l}84.48 \\
\pm 0.94\end{array}$ & 95.45 & $<.0001$ & NS & NS \\
\hline & Overall (trait) & $107.63 \mathrm{a}$ & $95.59 \mathrm{~b}$ & $84.06 \mathrm{c}$ & & & & \\
\hline \multirow{3}{*}{$\begin{array}{c}\text { Urea } \\
(\mathrm{mg} / \mathrm{dL})\end{array}$} & Baladi & $\begin{array}{l}39.12 \\
\pm 0.35\end{array}$ & $\begin{array}{l}46.47 \\
\pm 0.83\end{array}$ & $\begin{array}{l}70.91 \\
\pm 0.91\end{array}$ & $52.17 \mathrm{a}$ & & & \\
\hline & VL & $\begin{array}{l}39.75 \\
\pm 0.31\end{array}$ & $\begin{array}{l}44.15 \\
\pm 0.54\end{array}$ & $\begin{array}{l}63.89 \\
\pm 1.48\end{array}$ & $49.26 \mathrm{~b}$ & $<.0001$ & $<.0002$ & $<.0003$ \\
\hline & Overall (trait) & $39.44 \mathrm{c}$ & $45.31 b$ & $67.40 \mathrm{a}$ & & & & \\
\hline \multirow{3}{*}{$\begin{array}{c}\text { Creatinine } \\
(\mu \mathrm{mol} / \mathrm{L})\end{array}$} & Baladi & $\begin{array}{c}0.78 \\
\pm 0.02\end{array}$ & $\begin{array}{c}1.29 \\
\pm 0.04\end{array}$ & $\begin{array}{c}1.75 \\
\pm 0.08\end{array}$ & 1.35 & & & \\
\hline & VL & $\begin{array}{c}0.81 \\
\pm 0.02\end{array}$ & $\begin{array}{r}1.32 \\
\pm 0.02\end{array}$ & $\begin{array}{c}1.68 \\
\pm 0.07\end{array}$ & 1.27 & $<.0001$ & NS & NS \\
\hline & Overall (trait) & $0.79 \mathrm{c}$ & $1.31 \mathrm{~b}$ & $1.72 \mathrm{a}$ & & & & \\
\hline
\end{tabular}

\subsubsection{Carcass}

Edible parts of carcass is the important parts to show quality meat of the animal, so, the infected groups were gave abnormal measures. In this study the control group for both strains recorded a highly significant decrease $(P<.0001)$ to carcass percentage value compared to infected groups with 10 and $20 \mathrm{MC}$. Strain effect didn't show a difference between V-Line \& Baladi intra the 10 and $20 \mathrm{MC}$ treated groups. The results show how the carcase performance characteristics, assessed according to international standards agreed within the European Union, deteriorate when liver fluke is present which is detrimental to the value of carcass (Sanchez-Vazquez and Lewis, 2013). These re- sults are agreed with findings of (Mesele et al 2012).

\section{Blood parameters}

Table (5) Showed the mean values of total serum Protein in control groups and groups infected with $10 \mathrm{MC}$ were significant, while the infected groups treated with $20 \mathrm{MC}(\mathrm{P}<.0001)$ were highly significant than other groups. Ali (2012) stated that percent changes of serum protein concentration from rabbits infected is very high.

Table (5) has shown Albumin levels is high significant $(P<.0001)$ for normal control groups because the difference individuality blood levels for each rabbit. 


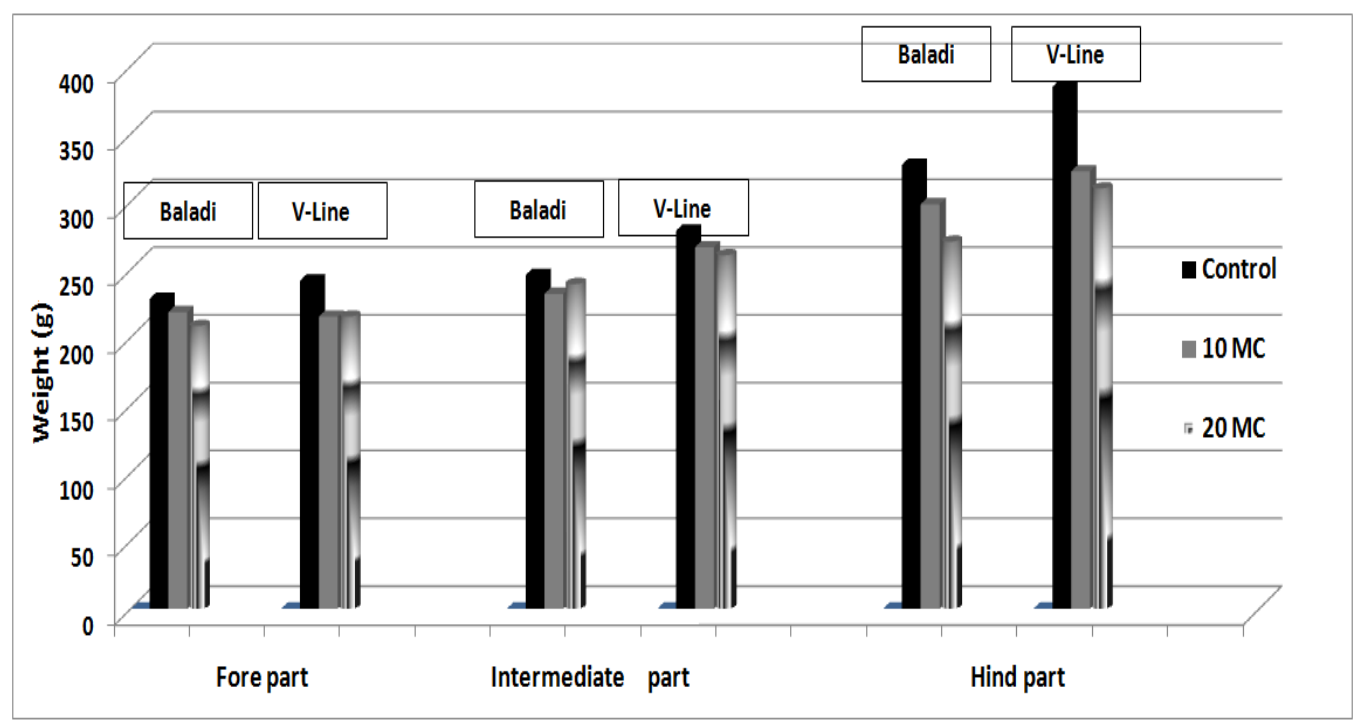

Fig. 1. Means of edible parts for carcass weight of two rabbit strains affected by fascioliases.

Our findings of abnormal albumin in this study are characteristic features of chronic and acute fascioliasis as in agreement with (Matanovic' et al 2007).

Regarding to activities of enzymes AST, ALT in blood of rabbits infected with $F$. gigantica, the results showed in (Table 5) referred to significant difference between male and female infected with $10 \mathrm{MC}$ groups and the other groups treated $20 \mathrm{MC}$ had highly significant $(\mathrm{P}<.0001)$ compared control. The same result recorded by (Ferre et al 1995) reported significant elevation in AST level 14 weeks post- infection. However, Teleb et al (2007) reported significant elevation in AST after 6 weeks post- infection; moreover serum ALT levels were elevated after 4 weeks post- infection.

Glucose level in blood of rabbit groups exposed to 10 metacercariae of $F$. gigantica were significant, but the groups exposed to 20 metacercariae were lower than control as follow $\left(107.63^{\text {aCont. }} \mathrm{mg}\right.$, $\left.95.59^{\mathrm{b} 10 \mathrm{MC}} \mathrm{mg}, 84.07^{\mathrm{c} 20 \mathrm{MC}} \mathrm{mg}\right)$. The difference between both strain was non-significant because the infected groups had been hardly impact ( 96.07 $\mathrm{mg}$ for "BB" and $95.46 \mathrm{mg}$ for "VL"). It was observed that a reduction in serum glucose levels was significantly lower $(p<0.05)$ in infected rabbits than control ones starting from 5 weeks postinfection even the end of the experiment (Phiri et al 2007).

Serum urea levels of treated groups for 20 metacercariae had been highly significant $(p<.0001)$ than the treated groups for 10 metacercariae compared to control due to Fasciola parasit- ism these results agreed with (Teleb et al 2007 and Rashed, 2008).

Serum creatinine recorded highly significant increase in infected group (BB) was $(1.36 \mathrm{mg} / \mathrm{dl}$ \& $1.67 \mathrm{mg} / \mathrm{dl})$, respectively. While, $(1.34 \mathrm{mg} / \mathrm{dl} \& 1.63$ $\mathrm{mg} / \mathrm{dl}$ ) in (VL) respectively compared control groups, this due to the effect of parasite metabolism in the kidney enzyme. This result in agreement with (Rashed, 2008), who reported that serum creatinine in rabbits infected with Fasciola gigantica highly significant compared with control group.

\section{CONCLUSION}

These results indicate that the rabbits exposed to F. gigantica infection $10 \mathrm{MC}$ or $20 \mathrm{MC}$ concentration of $F$. gigantica affected negatively on productive performance of Baladi rabbit herds.

\section{REFERENCES}

Ahmed, E.F., K. Markvichitr, S. Tumwasorn, S. Koonawootrittriron, A. Choothesa and S. Jittapalapong, 2007. Prevalence of Fasciola spp Infections of sheep in the Middle Awash River Basin, Ethiopia. Southeast Asian J. Trop Med Public Health, 38, 41-48.

Amer, S., ElKhatam A., Zidan, S.H., Feng Y. and Xiao L., 2016. Identity of Fasciola spp. in rabbits in Egypt.Parasites Vectors, 9, 6-23.

Ansari-Lari, M. and Moazzeni M., 2006. A retrospective survey of liver fluke disease in live- 
stock based on abattoir data in Shiraz, South of Iran. Prev Vet Med., 73, 93-96.

Bala, A.N., Garba A.E. and Yazah, A.J., 2011. Bacterial and parasitic zoonoses encountered at slaughter in Maiduguri abattoir, Northeastern Nigeria. Vet. World, 4(10), 437-443.

Blasco, A., Quhayaunand J. and Masoscro G., 1993. Hormanization of criteria and terminology in rabbit meat research. Rabbit meat research. World Rabbit Sci., 1, 3-10.

Charlier, J., De Meulemeester, L., Claerebout, E., Williams, D. and Vercruysse J., 2008. Qualitative and quantitative evaluation of coprological and serological techniques for the diagnosis of fasciolosis in cattle. Vet. Parasitol. 153, 44-51.

Dargie, J.D., 1987. The impact on production and mechanisms of pathogenesis of trematode infections in cattle and sheep. Int. J. Parasitol. 17, 453-463.

Doumas, B.T., Watson W.A. and Biggs, H.G., 1971. Albumin standards and measurement of serum with bromocresol green. Clin.Chim. Acta, 31, 87-88.

Duncan, D.B., 1955. Multiple Range and Multiple F -test. Biometrics, 11, 1 - 42.

Eman, K.A., Sherif M.B. and Reda S.F., 2016. Molecular characterization of Fasciola hepatica infecting rabbits fromEgypt based on mitochondrial and nuclear ribosomal DNA sequences. Res. J. Parasitol., 11, 61-66.

Ferre, I., Lopez, P., Gonzalo-Orden, M., Julian, M.D., Rojo-Vazquez, F.A. and GonzalezGallego J., 1995. The effects of subclinical fasciolosis on hepatic Secretory function in sheep. Parasitology. Research, 81 (2), 127131.

Greiling, H. and Gressner A.M., 1995. Lehrbuch der Klinischen Chemie und Patholiochemie. $3^{\text {rd }}$ ed. Schattauer Verlag, Stuttgart/ New York/USA. Vet. Med. 27(1), 5-7.

Hala, M.G. and Azza A.M., 2012. Growth performance, blood parameters and carcass characteristics of rabbits fed different levels of raffinose. Egyptian J. Nutrition and feeds, 15 (3), 503-511.

Haridy, F.M., Morsy, T.A., Gawish, N.I., Antonios T.N. and Abdel G.A., 2002. The potential reservoir role of rats and rabbits in zoonotic fascioliasis in Gharbia governorate, Egypt. J. Egypt. Soc. Parasitol., 32 (2), 561-570.

Harlod, V., 1975. Colorimetric determination of aspartate and alanine transaminase. Practical
Clin. Biochem., $4^{\text {th }}$ Ed. Harper and Row Publ. 1., New York, 294 P.

Hawkins C.D. and Morris R.S., 1978. Depression of productivity in sheep infected with fasciola hepatica. Veterinary parasitology, (4), 341351.

Hoglund, J., Morrison, D.A., Charlier, J., Dimander S.O. and Larsson A., 2009. Assessing the feasibility of targeted selective treatments for gastroin-testinal nematodes in first-season grazing rabbit based on midseasondaily weight gains. Vet. Parasitol. 164, 80-88.

Mahmoud A.Z., Taha, M.M., Afifi, S.M., Hassanein K.M. and Abdo A.M., 2010. Drug resistance and recent therapeutic measures in controlling of fascioliasis. Journal of American Science; 6 (11), 926-933.

Malone J.B., Gommes, R., Hansen, J., Yilma J.M. and Slingenberg J., 1998. A Geographic Information System on the potential Distribution and abundance of Fasciola hepatica and F. gigantica in East Africa based on food and agriculture organization databases, Elev Vet Parasitol 78, 87-101.

Mason, C., 2004. Fasciolosis associated with metabolic disease in a dairy herd, and its effects on health and productivity. Cattle Pract., 12, 7-13.

Matanovi, K., Severin K., Martinkovi, F., Impraga, M., Meaney M., Fairweather I., Brennan G.P., Ramasamy P. and Subramanian P.B., 2007. Fasciola gigantica: tegumental surface alterations following treatment in vitro with the sulphoxide metabolite of triclabendazole. Parasitology research 88, (4), 315-325.

Mendes, E.A., Vasconcelos A.C. and Lima W.S., 2012. HistopatHology of Fasciola Hepatica Infection in Merionesunguiculatus. Original Article, 41 (1), 55-62.

Mesele, G., Guadu, T., Bogale, B. and Chanie, M., 2012. Pathological Conditions Causing Organ and Carcass Condemnation and Their Financial Losses in Cattle Slaughtered in Gondar, Northwest Ethiopia. African Journal of Basic \& Applied Sciences 4 (6), 200-208.

Nour EI Din H.S., Ismail M.S., Maha F.S. and Mohamed G.H., 2005. Serological and Haematological Responses To Experimental Fascioliasis And Treatment. The Egyptian Journal of Hospital Medicine, 18, 124-132.

Peters, T., 1968. Determination of total protein in serum. Clinical Chemistry, 14, 11-47. 
Phiri I.K., Phiri A.M. and Harrison L.J.S., 2007. The serum glucose and $\beta$-hydroxybutyrate levels in rabbits with experimental Fasciola hepatica and Fasciola gigantica infection. Veterinary Parasitology, 143, Issues 3-4, 287-293.

Pisani, T., Gebski C.P. and Leary E., 1995. Accurate direct determination of high density uric asid, urea Assay. Arch. Pathol. Lab. Med. 119, 11-27.

Rashed, A.A., 2008. Effect of Fasciola gigantica on kidney of rabbits (Lagomorpha): Biochemical, histopathological and electrophoresis studies. J. Egypt. Soc. Parasitol, 38(3), 10491061.

Sanaa A.A., 2012. Evaluation of the immunological effect of beta alanyl--histidine against Fasciola gigantica antigens in rabbits. Original Article. J. Infect Dev. Ctries, 6(2), 166175.
Sanchez-Vazquez M.J. and Lewis F.I., 2013. Investigating the impact of fasciolosis on rabbits carcase performance: Veterinary Parasitology, 193, 307-311.

SAS Institute, 2004. SAS/ STAT User's Guide Version 9.1.3 edition: Statistics. SAS Institute Inc., Cary, NC/ USA.

Tasawar Z., Minir, U., Hayat C.S. and Lashari M.H., 2007. The prevalence of fasciola hepatica in rabbits around multan: Pakistan Vet. J., 27(1), 5-7.

Teleb, D.F., Soliman E.K. and Abd El- khalek T.M.M., 2007. Effect of fascioliasis on hematological, serum biochemical and histopathological changes in sheep. Egyt. J. Sheep, Goats Sci., 2 (2), 15- 34.

Trinder, P., 1969. Determination of blood glucose using an oxidase-peroxidase system with a non-carcinogenic chromogen. Journal of Clinical Pathology, 22, 158-161. 


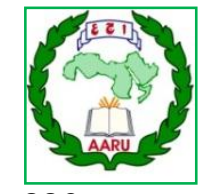

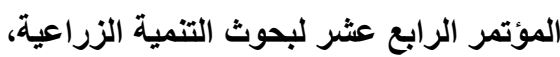

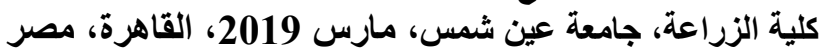

مجلد(27)، عدد (1)، عدد خاص مارس، مارس 2019 (886-877، 2019

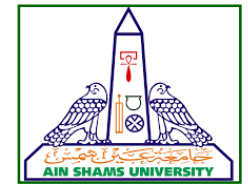

تأثير العدوى بالفاشيولا على الأداء الانتاجى وصفات الذبيحة فى الأرانب

[80]

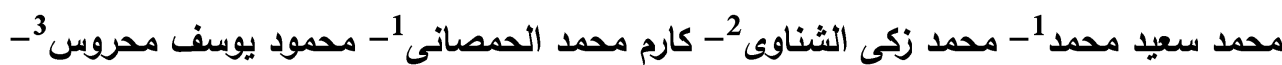
أحمد جلال السيد 3

1. قسم بحوث البيئة والرخويات - معهد تيودور بلهارس للأبحاث - الجيزة - مصر.

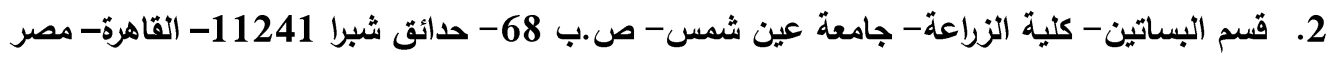

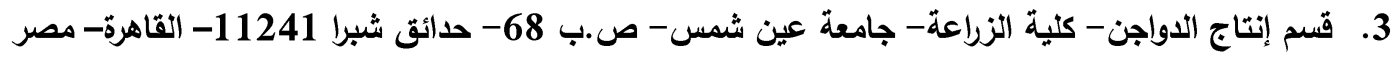

"Corresponding author: malacology_tbri@yahoo.com

Received 26 November, 2018, $\quad$ Accepted 30 December, 2018

فروق معنوية مرتفعة بين كل سلالة (p0.05> م) وكذللك

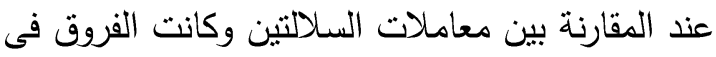
المعاملة على سلالة البلدى و الفى لاين مرتفعة

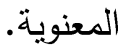

وكان متوسط الوزن عند مرحلة النضج الجنسى (كئ)

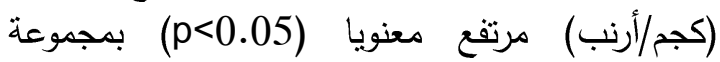

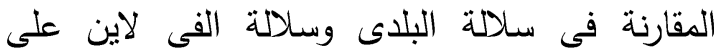

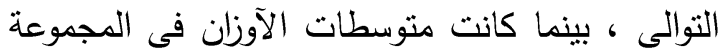

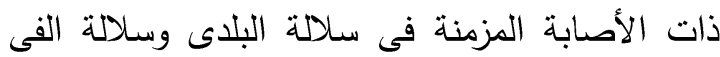

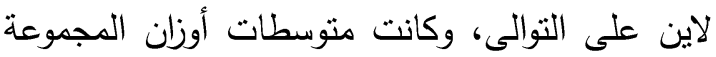

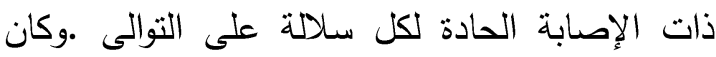
معدل الزيادة الوزنية للمتوسط العام لكلا السلالتين فى لكى

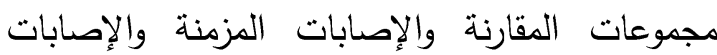
الحادة على التوالى • وكان معدل الإنستهلآك الغذائى الإنى

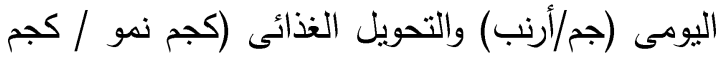

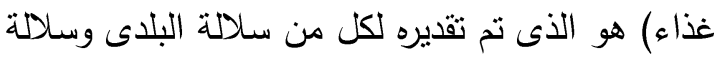
الفى لاين مقارنة بمجموعة المقارنة.

الكلمات الدالة: عدوى الفاشيولا، الأداء الإنتاجي، الذبيحة، الأرانب الأبمات

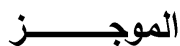

الهدف من هذه الدراسة تقييم تأثثير عدوى الفاثنيولا

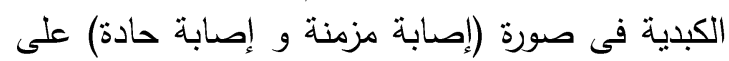
الدقاييس الإنتاجية على سلالتين من الأرانب البلدى

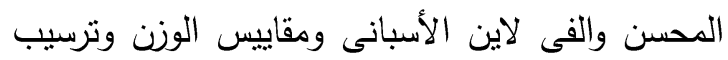

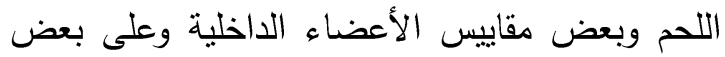
مقاييس الدم خلال فترة التجربة (12 أسبوع). إستخدمت فى هذه التجربة عدد 36 من الأرانب التب (التبان قسمت إلى 18 أرنب لكل سلالة في مرحلة التربية وكان متوسط الوزن كجم وقسمت كل سلالة إلى ثلاثة الته مجاميع بعدد 6 أرانب للمجموعة الواحده ، وتم إعطاء العدوى بالطفيل عن طريق الفم المجموعة الأولى مقارنة والمجموعة الثانية مصابة بعدد 10 ميتاسركاريا إصابة الطابة الطابية غير هميتة والمجموعة الثالثة مصابة بعدة 20 ميتاسركاريا إصابة مميتة من نوع فاثيولا جيجانتيكا.

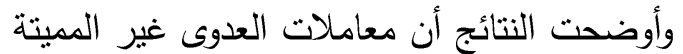
كانت أقل تأثرا بالطفيل ومرتفعة معنويا (P<0.05) وأكثر إرتفاعا للمعنوية (P<0.05) مقارنة بمجموعة بالطيا

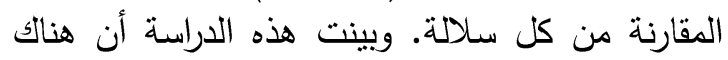

